\title{
Investigating Voice and Agency in Caryl Churchill's Selected Plays
}

\section{Zahra Khozaei Ravari}

\author{
Ph.D in English Literature, Assistant Professor, Department of Foreign Languages, \\ Faculty of Literature and Humanities, Shahid Bahonar University of Kerman, kerman, Iran \\ Email Address: zahrakhozaei@uk.ac.ir/zahra.khozaei@gmail.com
}

\author{
Doi:10.5901/mjss.2015.v6n4s2p409
}

\begin{abstract}
Caryl Churchill's plays have been studied from a number of perspectives. However, there have been few concerted attempts to investigate how the marginalized characters are given voice and agency to resist gender and class oppression as well as the issue of resistance to different kinds of oppression in her plays. Accordingly, this study aims to investigate these issue in two selected plays of Caryl Churchill Vinegar Tom (1976) and Top Girls (1982). This study employed Judith Butler's definition of agency to examine whether the characters are able to exercise agency and overcome oppressive forces. Their granted voice in criticizing oppressive forces is also examined as a tool to identify their resistance against patriarchal agents. It is found that each of Churchill's plays have revolutionary characters who resist oppressive forces in patriarchal societies that disadvantage them. Furthermore, this study extended the literature by discussing different forms of resistance to oppression in each play, and highlighting the fact that Churchill's plays have similarities and differences in the strategies that the characters take in resisting oppression. It also noted that not all the characters are able to overcome oppression.
\end{abstract}

Keywords: Agency, voice, Judith Butler, oppression, resistance

\section{Introduction}

The blatant abuse of women in male dominated societies had resulted in a continuous struggle by women throughout history who fought and are still fighting for equal opportunities as they attempt to improve their positions in the society they live in. Indeed, with the advent of globalization and information technology, women in many parts of the world have begun to fight for equality in the various domains of social life including politics, education and in the domestic sphere.

Different scholars and theorists have positive impact on illustrating women's oppression in different areas of societies including political as well as non-governmental spheres. In this regard, feminist scholars have made concerted attempts to destabilise the patriarchal system and men's systematic violence of women with an aim to "radically transform social, cultural, economic, and gender based systems of oppression" (Aston, 1999: 126). Among the scholars who had dealt with the issue of gender oppression and inequality are Juliet Mitchell (1974), Zillah Eisenstein (1979), Iris Young (1981), Linda Hartmann (1981), Allison Jaggar (1983), Lise Vogel (1983), bell Hooks (1984), Michele Barrett (1988), Judith Butler (1990), Chandra Talpade Mohanty, (1991), Mary Langan and Lesley Day (1992), and Lorna Fitzsimmons (1997). These scholars, who had struggled to end oppression in their respective ways, have the same opinion that the experience of oppression "transcends the boundaries of race, class, gender, and culture" (Hibbard 2005).

Non-governmental organizations and creative writers have also played their part in this struggle by challenging prevailing assumptions and stereotypes about women. For instance, creative literary writers have highlighted women's suffering by providing them a space so that their voices can be heard and the views listened to. Accordingly, the development of theatre had also played its part: women playwrights helped to foreground issues about women's struggle against patriarchal dominance in their plays. It is worthwhile to note that theatre had provided an avenue for women's voices to be heard in the public arena. In other words, theatre was not just a performance to be appreciated aesthetically but incorporated social criticism. Elaine Aston (1999) declares that "theatre can help women to see their lives politically: to raise awareness of oppression and to encourage women's creativity" (2).

There are several playwrights who worked on women's oppression. For example, Michelene Wandor's plays focus on chief feminist issues such as women and work, concern for children, custody and divorce. Her Care and Control, (1977) for example, deals with motherhood under attack and attempts to "challenge those who are socially empowered and use their roles to uphold the heterosexual, nuclear family above many other human values and it must fight to assure that women are treated as full and equal human beings" (Keyssar , 1984:137). Another writer, Megan Terry explores the relationships between males and females, the notion of power and traditional gender roles. Basically, the play is about 
the condemnation of traditional social and gender roles in contemporary society. This is undertaken in a manner that diverges from traditional plays: the actors and actresses in the play shift roles. Thus, it becomes 'impossible' to detect the unequal power relations between men and women because both sexes are illustrated in the same manner. In other words, men are characterised in terms of traditional female activities.

Caryl Churchill is a pioneer woman playwright. Her Vinegar Tom, Light shining in Buckinghamshire, and Cloud Nine are examples of plays that highlight the social roles of women through history. Churchill's collaboration with Joint Stock Theatre group had provided an avenue for her to use innovative theatrical devices that helped to conceptualize the internal dialogue related to women issues of her characters.

In addition, women in her plays are not just depicted as victims in a patriarchal society but as fighters and survivors. Churchill wrote her plays when Margaret Thatcher was elected as Prime Minister of England; as such her plays depict the dilemmas and conflicts of women living in the late seventies and eighties under the rule of the "Iron Lady". In essence, her plays explore issues surrounding gender. In addition, she also examined the complexities surrounding the relationships among family members, gender stereotyping and class struggles.

Caryl Churchill's plays have been studied from a number of perspectives. However, there have been few concerted attempts to examine women's resistance to oppressive forces which has not been given adequate attention in related studies. Previous studies have examined Ebtehal's "Women's Bodies in Dramatic Confrontations with Patriarchal Logic: The Representation of Violence against the Female Body in Contemporary Drama by Women" (2003) examines the violence against women's body but does not investigate their resistance. Similarly, Swanson's "Mother/Daughter Relationships in Three Plays by Caryl Churchill" (1986) brings up the oppressed situation of daughters caused by mothers without dealing with their attempts to resist such oppression. Fitzsimmons's "I Won't Turn Back for You or Anyone': Caryl Churchill's Socialist-Feminist Theatre" (1987) is another study that scrutinises the miserable life of women as a result of their socio-economic condition but does not dwell on the characters resistance against oppresive forces. Acordingly then, this study aims to investigate the resistance of women against their oppression and oppresive forces. In relation to this, the current study will look at the characters' voice and agency and how these factors play a role in the resistance of the women characters in Churchill's plays. This will help the researcher determine which characters are able to resist patriarchal and capitalist forces.

\section{Agency}

Normally, agency refers to the capacity of subjects to cause an event or action to happen. According to Monique Deveaux in "Agency" (2000) agency is central to feminist theorists because it indicates the extent to which women have the freedom and ability of action independently. On the other hand, the extent to which women are not able to exercise agency reveal their oppression and subordination. As one of the feminist theorists, Butler claims that subjects can just exercise agency when they are not restricted by society. Butler further posits that even a subject's free will might be constructed by society. Thus, a subject's agency might not even be representative of his/her real individual will. In this study, Butler's definition as the Agency of the marginalized characters in plays of Caryl Churchill can be best understood using her definition of Agency. A subject's agency might not even be representative of his/her real individual will. Consequently, Butler views one's agency as being limited within the realm of society and argues that a subject is only able to exercise agency if there is repetition of behaviours by him/her. It is through this variation that a subject can make sure his/her habits and behaviours are not affected and shaped by the surrounding society (2003).

In Butler's definition, agency is extremely dependent on the subject's surrounding society. To put it simply Butler does not separate a subject from society. As Fiona Webster in "The Politics of Sex and Gender: Benhabib and Butler Debate Subjectivity" (2000) argues, Butler is unlike De Beauvoir who believes that "agency is clearly a capacity of the subject" (12). For Butler agency is an effect of the subject and "not a quality or attribute which subjects somehow possess and deliberately exercise, but rather is an effect of the very processes through which they are constituted as subjects" (12). In other words, Butler does not separate the 'doer' from the 'deed' and hence the 'doer' is always constituted in and through the 'deed' as far as Butler is concerned.

Besides agency, the extent to which the characters are granted voice is also examined. Specifically, the voice and agency of the characters are scrutinized to examine the extent to which they are able to defend their rights and/or oppose their oppressive forces. This will help to identify the strategies taken by women and marginalized groups to resist, question and challenge the dominant patriarchal discourse prevalent in society. Voice and Agency of characters will be examined to observe whether Churchill's characters have voice and are able to exercise agency or not. This will help the researcher determine which characters are able to resist patriarchal and capitalist forces. The study relies on the ideas of Judith Butler, the post-modern feminist theorist from the Third Wave of Feminism. For the sake of methodology, it will be 
discussed that agency is used to show how marginalized characters challenge both gender and class oppression. Churchill has provided agency to some of her characters to resist gender and class oppression. Hence, Agency of the marginalized characters in plays of Caryl Churchill can be best understood using Butler's definition of Agency.

\section{Review of Related Literature}

Churchill's concern with issues related to women and their situation in society as reflected in her plays has been a subject of much discussion. An early example is Alisa Solomon (1981) which deals with this issue in four of Churchill's plays: Owners, Vinegar Tom, Light Shining in Buckinghamshire, and Traps. In her study, she labels Churchill as a feminist and socialist writer who has the ability to "interweave historical data, dramatic representation, and the non-illusionistic theatricality of that representation" (54). Solomon also claims that Churchill is a political playwright, who uses her plays to showcase the effects of particular political and social policies on the lives of members of the society. In her view, Churchill's plays make us think deeply about issues pertaining to the objectification of women, the values related to bourgeois life and western society's desire for material possession.

In another study Linda Fitzsimmons (1988) explores Churchill's socialist feminism trends through the lens of Heidi Hartmann. She argues that Churchill's plays portray some financially successful women. However, despite the presence of sucessful women, her plays draw our attention to the miserable life that women experience because of their poverty. According to Fitzsimmons, Churchill's awareness of the political climate of Britain in the 1980s that had disadvantaged women economically had acted as a catalyst for her to showcase the plight of women in her country and elsewhere. In addition, she claims that Churchill also had portrayed the struggle of such women either individually or collectively to challenge gender inequality.

Joan Teresa Hamilton (1991) dissects a number of Churchill's plays such as Fen, Soft Cops, light shining in Buckinghamshire, Top Girls, Hot Fudge, Ice Cream and Serious Money to tease out the notions of subjectivity via concepts from Louis Althusser, Michel Foucault as well as Jean Baudrillard. Basically, she attempts to highlight the extent to which Churchill tries to present the possibility of social changes in society. Her study's main concern is whether the women characters in the plays are subjected to male ideology via language and how they challenge this. In doing so, she draws inspiration from Althusser's idea of interpellation and Foucault's ideas on the relationship between discourse and power. She claims that some characters, in fact, are afraid to challenge the prevailing social order, while some are shown to desire social changes in their individual lives and subsequently in the wider society. Hamilton, however, notes that the characters in each play find their struggle for change difficult as they are controlled by the power of authorities (Foucault), making their struggle an uphill battle (Althusser).

Lisa Merrill (2001) investigates Churchill's critique of societies built on capitalist values which confine and restrict human moralities. For example, in her analysis of Owners, she highlights the character of Marion, who is depicted as a financially successful woman who is not dependent on others. She claims that Marion exhibits capitalistic values as she exploits the poor for her own financial gains. She further describes Marion as a 'monster' who can be equated with "a male-identified notion of power" (62). She adds that in Churchill's plays the success of women can only be possible if women take on the established male-notion of power and disregard their traditional stereotypical roles of a wife or mother.

Ebtehal A. Ahmad (2003) examines three types of violence against women's bodies in terms of "the political, the medical, and the social violations" (iii) in the works of several dramatists including Caryl Churchill's Vinegar Tom. She argues that women in Churchill's plays suffer from sexual abuse, isolation, feelings of fear and guilt. Meanwhile, Danelle Rowe in "Power and Oppression: a Study of Materialism and Gender in Selected Drama of Caryl Churchill" (2003) investigates how Vinegar Tom (1976), Cloud Nine (1979), Top Girls (1982), Fen (1982), and Serious Money (1987) offer a socialist feminist critique of women's oppression. He concludes that "traditional relations of power" (142) are the cause of women's oppression.

Carin Bigrigg (2004) compares the work of several playwrights in their historical contexts. In her opinion, Churchill's Light Shining in Buckinghamshire (1976) provides a link between history and the present time in which individuals attempt and fail to create more social equality through revolution or riot. She also claims that the miserable life of women who surrender willingly to the roles assigned to them is a reflection of the social roles accorded to women in present-day society. Hence, she believes that such works are actually a manipulation of the past to critique the present especially in their portrayal of violence and power by men against women.

Laura Leigh Whitaker's work (2007) which is pegged on Butler's Gender Trouble (1990) and Bodies that Matter (1993), investigates subjectivity and agency in the characters of Cloud Nine. She asserts that through the challenges of gender and normative behavior, Cloud Nine reveals Butler's concept of agency. She claims that by reading Cloud Nine 
through Butler, the reader is able to "question the process by which the destabilized subject gains and exercises agency" (v). The author affirms that Butler's and Churchill's ideas coincide with regard to the issue of subjectivity and agency. In analyzing Cloud Nine, Whitaker uses Butler's claim that gender or sex on its own does not determine one's subjectivity. Instead, it is derived from the many intersecting characteristics, such as ethnicity, class, and race. Society demands that subjects are defined by gender roles and no one questions the assignments of these roles or act against them. In other words, it is society that mandates "a gender role that the subject becomes or assumes" without any resistance. (16). Throughout the play the audience can recognize that the character's subjectivity is not based on their gender or sex because these characteristics are socially constructed. Based on these concepts, Whitaker focuses on each character individually and investigates which characters exercised agency in the play and which do not.

Georgiana Vasile (2010) tries to examine whether Caryl Churchill offers any solution for women's oppression in Top Girls. She also examines whether the women in the play can be labelled as friends or enemies. Accordingly, she concentrates on the conversations among women in different parts of the play. She shows how the women of the dinner party interrupt each other's talks, show their disagreement and have conflicts with each other. She concludes that Caryl Churchill in Top Girls does not suggest any "cause nor solutions for women oppression...but simply records the voices of different women" (256).

\section{Analysis}

The main aim of this study is to show how marginalized characters are given voice and agency to resist gender and class oppression. In order to achieve this goal, the researcher examines the characters' free will and whether the society they lived in allowed them to fulfil their desires. This was undertaken by examining the ability of characters to act differently in various situations. The researcher also discusses the situation of women in order to examine the characters' resistance.

\subsection{Vinegar Tom}

Vinegar Tom begins with a definition of witches in England during the earlier centuries. It shows Churchill's portrayal of witches who are harmed by people of their community. There are five women in the play who are accused of being witches: Joan, an old beggar widow who does not associate with the other villagers; Alice, a promiscuous single mother who has sex outside of marriage and rejects the moral order of the society; Susan, a mother who had experienced several miscarriages and attempts birth control; Ellen, a midwife and a "cunning woman" who practices healing and Betty an unmarried rebellious girl who does not want to get married. Joan and Ellen are hanged, Alice and Susan will probably face the same fate, and Betty is tortured until she agrees to be wed. Churchill questions the oppression of women of Britain in the twentieth century by alluding to witches.

Vinegar Tom is a play about the oppression of women which has continued throughout history. The play reminds us of Johnson's assertion that "for women, gender oppression is linked to a cultural devaluing of femaleness itself. Women are subordinated and treated as inferior because they are culturally defined as inferior as women" (24). Churchill cleverly uses the history of persecuting witches in England in the seventeenth century to illustrate this. In other words, she merges the idea of witchcraft from the seventeenth century with the patriarchal and capitalist oppression being practised in the modern time; all to denote the ever-existing marginality of women. I opine that she has successfully combined historical events with the notion of women's oppression in this play.

In Vinegar Tom there are both men and women who are patriarchal agents who victimise women, some who endure their situation without resistance. For instance, Susan showcases the characteristics of a 'typical' woman who does not resist the oppressive forces at all.

However, Churchill's aim is not only to illustrate the plight of muted marginalized groups, but also to create revolutionary characters to criticize patriarchy and capitalism. This is established through Betty who primarily does not accept her father's decision to marry the person she does not like, through Joan who struggles to convince the witch finders that she is not a witch but eventually succumbs in scene eighteen and through Alice who opposes the witch finders and never accepts that she is a witch. Through these characters, Churchill questions the subjugation of women in patriarchal societies. The characters' degree of resistance is determined by their voices and the ability to exercise agency. Thus resisting oppression in Churchill's Vinegar Tom takes various forms. For instance, through questions (Betty and Alice), revelation of unhappiness (Betty) or by escaping from authority (Betty). These characters exemplify that they have voices to resist the accepted norms of their society, although their agency is limited.

The miserable life of these characters is not a result of their sex but also because of their social class. In other words, in Vinegar Tom the intersection of gender and class oppression creates a 'double oppression' for women. The 
power and injustice practised by both patriarchy and capitalism are seen in relation to four working class women and one middle class woman in the play. The working class women are economically poor and disadvantaged because of this while the middle class girl is forced to surrender to the decision of patriarchal agents to stay alive. The lives of these women are not only shaped by men but also by women. It is where Margery, the first oppressor recognizes and introduces the stereotypical witches and Goody; the second oppressor, catches and hangs them. Kramer and Sprenger, the two other oppressors confirm this action by saying, "All witchcraft/comes from carnal lust/ which is in woman/ insatiable" (Plays One 178). Vinegar Tom further displays how people with socially constructed genders can be agents of patriarchy and consequently, oppress women.

In this play Churchill has attempted to highlight the patriarchal and capitalist behaviours which have made women's oppression and subjugation commonplace. She also has illustrated the powerlessness of marginalized groups while at the same time created subversive characters through whom she criticizes patriarchy and capitalism.

Resistance to oppression in Vinegar Tom is reflected via Alice who is the only rebellious character in the play who attempts to resist oppressive forces from the beginning to the end. Alice, the revolutionary character of the play, lives pleasurably with men and has an illegitimate child. She is given a voice to re-delineate patriarchal conventional terms more than the other stereotypical women. Her expressed need for freedom makes Alice different from a stereotypical woman in such a society. Although she is unable to escape from society's expectations in relation to womanhood, she, nevertheless, openly condemns them. In return, she is condemned by the community for her actions and beliefs. In relation to Butler's notion of agency, the researcher concludes that Alice's agency is limited by the boundaries of her society. Thus, she is unable to exercise agency freely even though she is granted a voice to defend herself.

Patriarchal societies regard women as subordinates to deny them their agency, as seen via Alice. In relation to this, Lloyd in Beyond Identity Politics Feminism, Power \& Politics (2005) asserts that "Women's agency is effaced; their negotiation of gendered identity and practices of femininity occluded; and they are presented, instead, as creatures upon which gender stamps its imprint" (91). As these statements illustrate, lacking the right to voice and agency makes women subordinates.

Alice, the revolutionary character, can be regarded as the feminist voice in general and Churchill's voice in particular. In fact, in my opinion all of the oppressed characters of the play are Churchill's voice. Even though some like Susan or Ellen are less active and do not directly criticize the patriarchal oppressors, and some other like Alice and Betty do not simply accept what is imposed on them, all of them direct the readers' minds to the oppressive role of women in society. Churchill transmits her feminist voice to condemn patriarchal and capitalist forces through these characters. However, Alice is the only one of these women who does not accept the witch finders' rules in identification of witches.

Alice is also more inspiring than the other women characters as she struggles against oppressive forces from the beginning to the end. Her statements at the end of the play can be regarded as a starting point for women's revolution against society's oppressive agents. It is believed that Churchill wants to portray that women can still have a voice even if they are oppressed. In fact, by casting Alice Churchill provides her with subjectivity. Salih (2000) proposes, "the idea that the subject is not a pre-existing, essential entity and that our identities are constructed, means that it is possible for identities to be reconstructed in ways that challenge and subvert existing power structures" (11).

With reference to Butler's theory of gender Alice and other witches of the play are unable to exercise agency, as according to Butler when a subject is confined with his/her society, his/her agency is limited. Churchill's aim is not only to illustrate the plight of muted marginalized groups, but also to create revolutionary characters to criticize patriarchy and capitalism. This is established through Betty who primarily does not accept her father's decision to marry the person she does not like, through Joan who struggles to convince the witch finders that she is not a witch but eventually succumbs in scene eighteen and through Alice who opposes the witch finders and never accepts that she is a witch. Through these characters, Churchill questions the subjugation of women in patriarchal societies. The characters' degree of resistance is determined by their voices and the ability to exercise agency. Thus resisting oppression in Churchill's Vinegar Tom takes various forms. For instance, through questions (Betty and Alice), revelation of unhappiness (Betty) or by escaping from authority (Betty). These characters exemplify that they have voices to resist the accepted norms of their society, although their agency is limited.

It can be concluded that the witches in Vinegar Tom are unable to exercise agency because of the boundaries set by society. In the sense, Churchill's aim was to illustrate how marginalized groups cannot exercise agency. At the same time, Churchill also creates 'revolutionary' characters such as Alice, Betty and Joan who criticize patriarchy and capitalism by giving them voices. Resistance to oppression in the play takes various forms: via questions (Betty and Alice), articulating their unhappiness (Betty) or by escaping from the oppressive forces authority (Betty). 


\subsection{Top Girls}

The other play in which voice and agency can be applied is Top Girls. The play depicts the story of different women of the past and present who have unsuccessfully struggled against patriarchal norms. Top Girls is a play about two classes of women in society and how middle class women oppress working class ones in the patriarchal/capitalist society of Margaret Thatcher's time. The play shows that the oppression of women is rooted in the fact that we live in a society with distinct class hierarchies. So, some women who are successful within these class hierarchies have to victimize the members of their own sex. This class hierarchy had an impact on women's social and familial relationships. Although class brings wealth, predominance, and reputation to women, it breaks the familial relationships especially when the middle class ones do not pay attention to the working class members.

There are class hierarchies between Marlene and other women around her. Marlene is on top while Nell and Win are lower than her in the hierarchy, Mrs. Kidd is lower than Nell and Win, the interviewees are lower than Mrs. Kidd and finally Joyce and Angie are at the bottom of the hierarchy. Indeed, Marlene, her sister, and her daughter are on the two extremes, on top of and at the bottom of the hierarchy.

In the play, Churchill demonstrates that class is the source of oppression of marginalized communities. Consequently, working class women are dominated and repressed by middle class ones who benefit from the society's strategies which discriminate different classes. She tends to criticize Thatcher's policies and defend socialist ideas by showing how working class characters are trapped in a system of economical and familial relationships. In addition, the play illustrates and criticizes Thatcher's other policies such as privatization in economy and education as well as Individualism. Top Girls also illustrates Butler's gender perspective, in which a person with female sex, does not necessarily own a feminine gender. As a result, Marlene owns a masculine gender, due to her male behaviour which are repeated and shapes her gender.

On a final note, I wish to note that the title of the play is itself an irony as there is a disconnection between "Top" (a pinnacle) and "Girls" (a diminutive suggesting immaturity and helplessness). All the historical women who attend Marlene's celebration dinner are famous (or infamous) for having done things socially permissible only for men, or for the things that men did to them. For example, as Pope Joan explains, "women, children, and lunatics can't be Pope" (Plays Two 69). Each had the ability to do that for which she is remembered, but each was punished by her society for the affront. In Marlene's world (just as in those of her dinner party guests) "success" is measured by male standards. Thus, advancement in the capitalist business world is possible only for those women who forsake "feminine virtues" (raising children, nurturing family members, etc.). Marlene could become a managing director only because Joyce raised her daughter, but that sacrifice and caring for their widowed father provides no societal respect or protection for Joyce, who was abandoned by her husband and hated by Angie.

Top Girls like Vinegar Tom portrays characters who resist oppression through different means. Lady Nijo resists authority in a direct manner by leaving the oppressive forces of authority (the palace). Dull Gret, on the other hand, becomes aggressive while Joyce questions and criticizes patriarchal and capitalist behaviour. Pope Joan attempts to resist patriarchy subtly by adhering to patriarchal norms and values. Besides, there are also characters who simply endure oppression without any resistance or struggle which is exhibited by Griselda and the interviewees who sought jobs at the Agency.

Analyzing this play for investigating the voice and agency, the researcher focuses on a more biting satirical look at Thatcher's policies and her great socio-political influence on working class women in Top Girls. As Langan asserts,

The term 'mixed economy of welfare' implies a false counter-position between the (private) sphere of the capitalist economy which operates according to rigorous free market principles and the (public) world of welfare which caters simply to social need (88).

So, as a member of a marginalized group in Thatcher's time, Churchill criticizes the mixed economy of welfare, privatisation, and capitalist economy proposed by the Right wing party in this play. Writing the play she questions the personal achievement of a limited number of members of society. Top Girls was written three years after Thatcher won the election. It shows Thatcher's strategies regarding two classes of women: those from the working class who suffered from the lack of welfare benefits as well as those who belonged to the middle class who enjoyed the opportunities to have business careers. As Andy Williams in UK Government \& Politics (1998) asserts, in Britain the way people vote largely explains their social class. He argues that the middle class people vote for the Conservative party while the working class support the Labour party. In Top Girls two groups of people are identified: those who are marginalized and deprived can be labelled as working class and those who gain the benefits can be labelled as middle class.

The play concentrates on the life of a successful Conservative business woman during Thatcher's reign who loses her humanity in order to attain power in a male dominated society. The researcher argues how Churchill strictly and 
closely criticizes Thatcher's economic policies which undermined and disadvantaged working class women. As a member of the marginalized group in Thatcher's time, Churchill criticizes her economic policies via the play. In this respect, Churchill criticizes bourgeois feminism in which a successful woman does not pay attention to working class ones. In this play also the researcher will examine which characters have voice and excersice agency to examine how they are able to resist oppression.

In their examination of voice, in Top Girls the researcher found that the guests of the surreal dinner party Isabella Bird, Lady Nijo, Dull Gret, Pope Joan, of Act One are granted voice to criticize their societies. In Act Two there is only one working class woman, Joyce, who is granted voice to criticize the patriarchal society and is, thus, able to exercise agency. Even Marlene, the top manager of the employment agency is unable to exercise agency. This is because she is portrayed as a patriarchal agent and is, thus, unable to change her behaviour in different situations. Resistance to oppression also takes different forms in this play: from a more direct manner like completely abandoning the oppressive forces of authority (Lady Nijo), getting aggressive (Dull Gret) and questioning patriarchal and capitalist behaviours (Joyce). Pope Joan tries to overcome oppression by 'transforming' into what is acceptable in patriarchal societies. Besides, there are also characters who simply endure oppression and do not even complain about their situation (Griselda (Act One) and the interviewees (Act Two)).

Churchill in the guise of this aggressive character expresses herself. Joyce is granted voice, while the interviewees as marginalized groups remain silent and submissive. At first it seems Marlene is more impressive to the audience in comparison to the marginalized characters including Joyce, as unlike the other women in the play, she is successful in business, is dominant, wealthy, and repudiates women and struggles for her rights in a patriarchal and capitalist society. However, as the play proceeds, it becomes obvious that Joyce is more impressive. The character of Joyce embodies Churchill's giving voice, superiority and priority to subverted and muted groups by making them subversive.

The findings here are in tandem with Fitzsimmons' (1988) claim that Churchill had portrayed the struggle of such women as a means to challenge gender inequality. Additionally, the findings supports Hamilton's (1991) argument that Churchill's characters are depicted in a bipolar fashion - either as being afraid to challenge the prevailing social order or being brave to desire changes in the social structure. The findings are also similar to Hamilton, who notes that the characters find their struggle for change difficult as they are controlled by the power of the authorities.

\section{Conclusion}

This article contributes to the body of literature by examining the resistance to gender and class oppression. Accordingly, it employed Butler's definition of agency to examine whether the characters are able to exercise agency and overcome oppressive forces. Their granted voice in criticizing oppressive forces is also examined as a tool to identify their resistance against patriarchal agents. Our study extended the literature by discussing different forms of resistance to oppression in each play, and highlighting the fact that Churchill's plays have similarities and differences in the strategies that the characters take in resisting oppression. It also noted that not all the characters are able to overcome oppression.

\section{References}

Hibbard, N. (2005). Popular Public Resistance Hip-Hop Culture's Instrumental Role in Challenging Neoliberal Hegemony and Globalization. Paper presented at the Democracy and Globalization Kent, Ohio.

Aston, E. (1999). Feminist Theatre Practice: A Handbook. London: Routledge.

Keyssar, H. (1984). Feminist Theatre: Introduction to Plays of Contemporary British and American Women. London: Palgrave Macmillan. Swanson, M. (1986). "Mother/Daughter Relationships in Three Plays by Caryl Churchill". Theatre Studies, 31, 49-66.

Fitzsimmons, L (1987). "I won't turn back for you or anyone': Caryl Churchill's Socialist-Feminist Theatre". Essays in Theatre 6(1), 19-29. Deveaux, M. (2000) "Agency" in L. Code (Ed.), Encyclopaedia of Feminist Theories. London: Routledge.

Webster, F.(2000). "The Politics of Sex and Gender: Benhabib and Butler Debate Subjectivity." Hypatia 15.1,12.

Solomon, A. (1981). "Witches, Ranters and the Middle Class: The Plays of Caryl Churchill". Theatre, 12(2), 1981, 49-55.

Hamilton, J.T. (1991). "Fen and Hot Fudge: A Study of Subjectivity and Agency in the Drama of Caryl Churchill." University of Lincoln Nebraska.

Merrill, L. (2001). "Monsters and Heroines: Caryl Churchill's Women." Modern Dramatists a Casebook of Major British, Irish, and American Playwrights. ed. Kimball King. New York: Routledge.

Ahmad, E.A. (2003). "Women's Bodies in Dramatic Confrontations with Patriarchal Logic: The Representation of Violence against the Female Body in Contemporary Drama by Women." Ball State University, Indiana.

Bigrigg, C. (2004). "Women (w)ri(gh)ting wrongs: Contemporary female playwrights manipulate the pas. PhD Thesis, the University of New Mexico, Mexico.

Whitaker, L. (2007) "'Unstable Subjects": Gender and Agency in Caryl Churchill's Cloud 9." Auburn University. 
Vasile, G. (2010). "The Female Voices in Caryl Churchill's Top Girls (1982): Sisters or Foes." Anagnorisis, 1, 256.

Johnson, A. G. (2005). Gender Knot : Unravelling Our Patriarchal Legacy. Philadelphia, PA, USA Temple University Press.

Churchill, C. (1985). Churchill: Plays One: Owners, Traps, Vinegar Tom, Light Shining in Buckinghamshire, Cloud Nine. London: Methuen.

Lloyd, M. (2005). Beyond Identity Politics Feminism, Power \& Politics. London: Sage Publications Ltd.

Salih, S. (2002). Judith Butler. Canada: Routledge.

Churchill, C. (1990). Churchill: Plays Two: Softcops, Top Girls, Fen, Serious Money. London: Methuen.

Langan M \& Day. L. (1992). Women Oppression and Social Work, Issues in Anti-Discriminatory Practice. New York: Routledge.

Williams, A. (1998). Uk Government and Politics. Oxford: Heinemann Educational Publishers. 